\title{
Evaluation of production, consumption and nutritive value of gurasa, an Indigenous Flat Bread of North-Western Nigeria
}

\author{
Agbara,Gervase Ikechukwu ${ }^{1 *}$; Bade, Aminu ${ }^{2}$ Ali,Sadiya Halima ${ }^{3}$;dams Mustapha,Fannah ${ }^{1}$ \\ ${ }^{1}$ Department of Food Science and Technology, University of Maiduguri, PMB 1069 Maiduguri, Nigeria. *Corresponding Author \\ ${ }^{2}$ Department of Food Science and Technology, Kano State University of Science of Technology, Wudil, PMB 3244 Kano, Nigeria; \\ ${ }^{3}$ National Biotechnology Development Agency, Bayero University, Kano Nigeria; haleemabaffa123@yahoo.com.
}

\begin{abstract}
A survey was conducted using structured questionnaire to evaluate the production and consumption pattern of gurasa, an indigenous flat bread consumed in northwestern Nigerian comprising of seven States. Also nutritive value of randomly selected gurasa samples were analyzed. Ninety eight percentage (98\%) sampled consume this product,and at any time of the day $(52 \%)$ and few others for breakfast(27\%), usually accompanied with yaji(spiced defatted peanut powder)(54\%). More producers were males $(25.7 \%)$, more consumers $(32 \%)$ females mainly in the age group of 21-31. Kano, Katsina, Kaduna, Jigawa harbour $74.3 \%$ of producers and $79 \%$ of consumers. Keeping quality was less than five days (60\%), less three days (40\%), therefore improvement in keeping quality $(41 \%)$ and nutritional $(37 \%)$ were solicited. Yong adults were the main producers who obtained the skill from parents/relatives(91\%), those with less than five years of experience were $40.5 \%$ and $6-11$ years of experience, $43.3 \%$. Local oven $(81 \%)$ fueled by corn stalk $(75.7 \%)$ was involved in baking. The need for expansion called for assistance in the area of working capital $(56.75 \%)$ and provision of storage facility $(36.72 \%)$ to further improve profitability through greater turnover. Moisture, protein, fat, ash, dietary fiber and carbohydrate contents of sampled gurasa varied significantly $(\mathrm{p}<0.05)$ from $28.09-30.11 \%, 8.96-11.68 \%, 4.03-5.00,1.79-3.11 \%, 0.92-1.12 \%$ and $50.00-55.04 \%$. Weight, volume and specific loaf volume varied significantly from $108.34-119.27 \mathrm{~g}, 211.96-260.17 \mathrm{ml}$ and $1.93-2.22 \mathrm{ml} / \mathrm{g}$ respectively. It is suggested that government intervention is necessary to modernize, harmonize and regulate this subsector that help to eliminate food insecurity. Nutritional quality could be improved by partial substitution of the refined wheat flour with pulse flour since majority could not afford animal protein.
\end{abstract}

Key words:Flat bread,Gurasa,Nutritive value,Production survey,Consumption survey.

\section{Introduction}

What is commonly regarded as civilization is reared on cultivation and processing of cereal and wheat (Tritium aestivium) is the dominant of the three principal cereals, others are maize and rice. Wheat based foods have dominated traditionally re-known staples creating a homogeneity of diet among different cultures (Khoury et al.,2014). Wheat flour, a refined extraction of wheat endosperm consist mainly of starch and a small fraction of a unique protein called gluten consisting of glutenin and gliadin, these two are responsible for wheat dominant role in the production of baked goods (Shewry et al.,1992). Bread consumption dates back to Neolithic era, its production and consumption has kept pace with civilization cutting across all racial and cultural barriers of the world and for some bread is the main source of micro- and macronutrients (Abdel-aal et al.,1995; Ijah et al.,2016). Flat breads like western styled pan bread is made with three basic ingredients: flour, salt and water, it can be leavened or unleavened, but unlike pan bread the dough is given a short fermentation, rolled into flattened roundish shapes and baked at higher temperatures and shorter times for unique crust characteristics (Quail et al.,1990;Coskurna et al.,1999;Pahwa et al.,2016).

Flat bread predates pan bread and its spread is universal(Faridi, and Rubenthaler, 1983). India subcontinent alone harbours huge number of flat breads with such names as chapatti, parota, roti, puri etc. Wani et al.(2016) reported that chapatti, an unleavened single layered flatbread as the oldest and most consumed flat bread in the world and a contributor of substantial amount of dietary energy in take. Tortilla a similar unleavened single layered flat bread is common in Mexico and other Central and North American countries. In Middle East and North Africa the most popular flat bread is a double-layered Arabic bread variously called pita, shami, Syrian bread or pocket bread, of which Egyptian baladi is also a variant (Wani et al.,2016; Idrani et al.,2000). Lavash,Songak and barbari are staples in Iran while Injera and Gurasa are traditional foods of Ethiopia and Sudan respectively(Gocmen et al.,2009). It is believed that north Africans or Arab traders brought gurasa to Kano, once reknown ancient commercial center centuries before Nigerian independence (Ibrahim,2015). Similar flatbreads with similar names do exist in Middle East and North African. Amr (1988) recognized three categories (medium crumb, low crumb and crumbless) of flatbread 
on the basis of crumb structure; Qarooni(1996) identified two types: single or double layered either leavened or unleavened. According to (Pahwa et al.,2016), flatbreads are usually made with flour of high extraction, they are usually of low specific volume with high crust to crumb ratio. Gurasa production and consumption is deep rooted in northwestern Nigeria, a region mainly inhabited by the Hausa/Fulani ethnic nationality a big contributor to Nigeria population of 198 million(NPC,2018) and which is expected to be the third most populous country in the world by 2050.(World population prospects, 2016 Review)This region consists of seven States: Kaduna, Kano, Katsina, Kebbi, Jigawa, Zamfara and Sokoto. Gurasa production has remained a cottage business in this environment, rarely technology-driven. Flattened dough pieces obtained from mixture of wheat flour and ingredients are baked in a local oven called Tanderu, thereafter vendors collect their consignment in transparent polyethylene sacks for retailing. Gurasa is eaten as the main or side meal accompanied with other well spiced light foods such as sauces, soups, suya(spiced roasted beef slices) yaji(spiced defatted groundnut cake mix) etc. As urban centres sprout up everywhere, the attendant life style changes for urban dwellers include crave for convenient foods and indulgence in eat-aways, therefore patronage for gurasa has continued to soar, being a cheaper alternative to more expensive pan bread. There are dearth of information on gurasa production in Nigeria such information include process or product specification, therefore each processor applies his/her innate wisdom and augment this with the little experience acquired during the apprenticeship which these days are short-lived. Good manufacturing and hygienic practices are usually ignored, high turnover and profit motives are on the front burner, consequently product quality are as diverse as the number of processors. Additionally, statistics of producers and consumers in the gurasa belt of Nigeria are lacking. Food security encompasses availability, accessibility and affordability of nutritious food (FAO, 2009). It is believed that the health and wellness of a people among others is linked to the nutritional composition of the commonest food available to them, and in this case gurasa. Therefore, the trust of this study was to evaluate the nutritive value, production and consumption pattern of gurasa in the seven States of northwestern Nigeria.

\section{Materials and Methods}

\section{Gurasa production and consumption pattern survey}

Separate structured questionnaires with relevant items were sent separately to commercial scale gurasa producers and consumers, for the later questionnaire items included: can you eat/produce gurasa, how long does it remain fresh, do you prefer gurasa over pan bread, if yes why, any need for gurasa improvement, if yes in what area. Questionnaire items for producers include the following: source of skill, experience(years) in business, ingredients/equipment used, fuel source/type, profitability, production problems and areas of government intervention. Apart from these questionnaire items stated here, items pertaining to demographics of the respondents were included such as: sex/age/state of origin. Convenience sampling technique was applied to obtain sampling units partly due to non-homogenous distribution of producers/vendors which are concentrated in the urban centers mainly the State capitals and the large geographical area involved. Three hundred and forty (340) questionnaires were distributed through vacating students of Kano State University of Science and Technology (KSUST) Wudil, Kano, Nigeria. The State capitals of the seven (7) States of northwestern Nigeria was the target population, unequal number of questionnaires were assigned to each of the State in decreasing order of their population as follows: Kano (80), Kastina (50), Jigawa (40), Kaduna (50), Zamfara (40), Sokoto (40), Kebbi (40). Another batch of fifty (50) questionnaires were designed and sent to the producers of gurasa mainly in Kano metropolis the epicenter of gurasa production in northwestern Nigeria, in addition to 30 completed through telephone interviews from the remaining six States. In most cases the required information were solicited and entered in the spaces provided in questionnaires by the facilitators. Data were transformed into percentage points and tabulated.

\section{Gurasa diameter and specific volume determination}

The volume $(\mathrm{ml})$ of individual gurasa samples were determined using rapeseed displacement method and the mass ( $\mathrm{g}$ ) obtained by weighing each in a weighing balance, while the diameter $(\mathrm{mm})$ of individual gurasa samples were measured using a ruler position centrally on the gurasa surface. Specific volume $(\mathrm{ml} / \mathrm{g})$ was obtained by dividing loaf volume by its mass.

\section{Collection and analysis of the nutritive value of gurasa.}

Fleshly baked gurasa samples were purchased from ten randomly selected producers in Kano metropolis. Experimental quantities were purchased, wrapped separately in transparent polyethylene films, code labeled with gurasa bread1, gurasa bread2..... (GB1, GB2 ......), there were taken to the laboratory and stored under refrigeration until needed for analysis. The moisture, protein, fat, ash, and crude fibre were determined according the procedures of AACC(2000). The moisture contents of gurasa samples were determined by drying $5 \mathrm{~g}$ in a hot air oven at $105^{\circ} \mathrm{C}$ for $3 \mathrm{hr}$. Total ash contents of gurasa samples were determined by ashing $5 \mathrm{~g}$ samples at $550^{\circ} \mathrm{c}$ for $5 \mathrm{hr}$ in a muffle furnace. Crude fiber contents were determined by digestion with trichloroacetic acid reagent under refluxing, filtered residue was washed and oven dried and finally ashed in muffle furnace, the difference in mass between the dried residue and the ash as a percentage of the sample weight was taken as the crude fibre content. Fat contents were determined by extraction of $2 \mathrm{~g}$ sample in Soxhlet extractor using petroleum ether for $5 \mathrm{hr}$, oven drying the extract at $70^{\circ} \mathrm{C}$ for 10 min. The crude protein $(\mathrm{N} \times 6.25)$ contents were determined using the micro-Kjeldahl method involving $200 \mathrm{mg}$ sample. Carbohydrate contents were obtained by “difference". Carbohydrate $(\%)=100-[\%$ moisture $+\%$ protein $+\%$ fat $+\%$ ash $+\%$ 
crude-fiber]. Food energy (E) (kcal/100g) were obtained by multiplying gross nutrients with Atwaters conversion factors and summing the same.

\section{Statistical analysis}

Proximate composition analysis was carried out in triplicates and the data subjected to one-way analysis of variance(ANOVA), means were separated using Fisher's Least Significant Difference (LSD) and significance were accepted at 5\%. SPSS version 16.0 was used for statistical analysis. Data obtained from the questionnaires were transformed into percentage points and the results tabulated.

\section{Results and Discussion}

A total of 340 questionnaires were distributed to consumers, 300 were returned and after sorting 276 were accepted representing $81.18 \%$ of the total sent out. 80 questionnaires were sent out to producers, 67 were returned, after sorting 61 or $76.25 \%$ were successfully returned.

\section{Age/sex distribution of gurasa producers}

In Table1a, $56.2 \%$ of producers were females against $43.8 \%$ males, the dominant age group was 21-32 years consisting of $25.7 \%$ males, equally in the age bracket $32-42$ years, $18.1 \%$ males vs $11.9 \%$ females. This information indicates that older individuals $(\geq 43)$ were non-existent in gurasa business. This goes to show the important role young females play in food preparation and distribution in this region of Nigeria, in order to ensure food availability an element of food security. This finding also points out the fact that these females were of school age, mainly adolescents. No male less than20 years was observed in gurasa production, were all females, $22.40 \%$. The seven states were grouped into two based on nearness to Kano mainly for simplicity: Kano, Kaduna, Katsina, Jigawa constitute group A while Zamfara, Sokoto, and Kebbi group B. Expectedly more gurasa producers(73.3\%) were found in group A against $25.7 \%$ in group B. This could be attributed to higher population density in each of the States in A than in B.

Table 1a. Age/Sex Distribution of Gurasa Producers in Seven States of Northwestern Nigeria

\begin{tabular}{|c|c|c|c|c|c|c|}
\hline \multirow[t]{2}{*}{ Age (yrs) } & \multicolumn{3}{|c|}{ Producers $(\%)$} & \multicolumn{3}{|l|}{ State of Origin } \\
\hline & Male & Female & Total & Group A & Group B & Total \\
\hline & & & & Kan. Kat.Jgw.Kad & Zam.Sok.Keb & \\
\hline$<20$ & 00 & 22.4 & 22.40 & 14.8 & 7.6 & 22.4 \\
\hline $21-31$ & 25.7 & 21.9 & 47.6 & 35.7 & 11.9 & 47.6 \\
\hline $32-42$ & 18.1 & 11.9 & 30.0 & 23.8 & 6.2 & 30.0 \\
\hline$>43$ & 00 & 00 & 00 & 00 & 00 & 00 \\
\hline Total & 43.8 & 56.2 & 100 & 73.3 & 25.7 & 100 Number of \\
\hline
\end{tabular}

Respondents = 276; kan=Kano, kat=Katsina, kad=Kaduna, Jgw=Jigawa zam=Zamfara, sok=Sokoto, keb=Kebbi

In Table $1 \mathrm{~b}$, the dominant sex for gurasa consumption were females(66\%) Vs males(34\%), mostly of the age bracket 21-31 years, $79 \%$ of them were found in group A States against $21 \%$ in group B. In all age brackets there were fewer male consumers(none recorded for $\leq 15$ years age group) than females and the tendency to consume gurasa decreased with age as Table $1 \mathrm{~b}$ indicates. This could be attributed to the fact that men eat less often than women and usually go for heavier meals than gurasa which is often taken as a light meal or snack.

Table1b.Age/Sex Distribution of Gurasa Consumers in Seven States of Northwestern Nigeria

\begin{tabular}{|c|c|c|c|c|c|c|}
\hline \multirow[t]{2}{*}{ Age (yrs) } & \multicolumn{3}{|c|}{ Consumers } & \multicolumn{2}{|c|}{ State of Origin } & \multirow[b]{2}{*}{ Total } \\
\hline & Male & Female & Total & Group A & Group B & \\
\hline & & & & Kan. Kat.Jgw.Kad & Zan.Sok.Keb & \\
\hline$<20$ & 0 & 15 & 23 & 17 & 06 & 23.0 \\
\hline $21-31$ & 20 & 32 & 52 & 43 & 09 & 52.0 \\
\hline
\end{tabular}




$\begin{array}{lcccccc}32-42 & 04 & 12 & 16 & 12 & 04 & 16 \\ >43 & 02 & 07 & 09 & 07 & 02 & 09 \\ \text { Total } & 34 & 66 & 100 & 79 & 21 & 100\end{array}$

\section{Number of Respondents $=\mathbf{2 7 6}$}

Consumption pattern of gurasa is presented in Table 2, the significant information was $98 \%$ of the respondents consumed gurasa implying that producers must work extra hard to feed teeming gurasa consumers. $\mathrm{FAO}(2016)$ reported the least moderate to severe form of hunger in this region of northern Nigeria with better food security indicators except economic access to food . More than half of the respondents(54\%)preferred to consume gurasa with yaji (spiced defatted groundnut cake mix); 30\% with Soup, $10 \%$ with Tea, others $(06 \%)$, any anytime of the day $(52 \%)$ either as breakfast meal $(24 \%)$ or as $\operatorname{lunch}(17 \%)$ and others $(07 \%)$.This implies that gurasa can be used as a vehicle of food fortification in a region reported to have endemic malnutrition(IITA,2003). Majority $(66 \%)$ claimed that the gurasa of freshness could not exceed 3 days, no respondent reported freshness duration of more than one six(6) days, a minority(34\%) agreed that gurasa could stay fresh for 4-6 days. However, it is known that stalling is more pronounced in flatbread than hearth bread, this condition can be exacerbated in tropical environment, with high moisture contents, poor hygienic observances in its production and distribution among others, therefore it is unthinkable gurasa freshness or shelf life would exceed a day without refrigeration. Yaji is a common ingredient in the cuisine of people of this region, it comes in different forms heavily spiced and salted. Sixty two (62) percent of respondents against 38\% claimed that gurasa was better than normal bread in eating quality (57\%), keeping quality (22\%) and nutritional quality(21). The love for gurasa in this region is high therefore normal bread producers would be struggling to breakeven, perhaps through the patronage of non-natives and high income earners. As for the need to improve gurasa, $61 \%$ agreed against $39 \%$ that disagreed, and the consenting consumers wanted an improvement in keeping quality $(57 \%)$, for some (39\%) nutritional quality, few others(05\%) eating quality. This shows why gurasa is eaten fresh from the fire because its sensory quality is known to deteriorate quickly after due to rapid onset of stalling. Commercial modern bread has contains anti-staling additives such as emulsifiers and enzymes that increase the freshness level of most bread.

Table 2: Consumption Pattern of Gurasa Northwestern States of Nigeria

Questionnaire Items $\quad$ Responses andNumber of respondents (\%)

Do you consume gurasa? $\quad$ Yes (98) No (02)

Consume with what?

Tea (10), Sauce(30), Yaji (54), Others (06)

At which time of the day?

Breakfast (27), Lunch (17), Supper (04), Anytime (52)

Freshness duration(days)

$1-3(66) \quad 4-6(34) \quad>6(00)$

Is gurasa better than Pan bread?

Yes $(62)$

No (38)

Better in which area?

Eating quality (21), Keeping quality(57), Nutritional quality (22)

Does it need improvement?

Yes (61), $\quad$ No (39)

Improving what?

Eating quality (05), Keeping quality(57), Nutritional quality (39)

\section{Number of Respondents $=\mathbf{2 7 6}$}

In Table 3 the production pattern or dynamics of gurasa is presented. Majority $(84.8 \%)$ of the producers had spent less than 11 years in gurasa production, a skill mainly transmitted from parents/relatives(91\%)others, aroma(24.32\%). Daily profit agreed by majority $(66.5 \%)$ was 3000-5000 Nigerian Naira equivalent to7.5-12.5 US Dollars. The problem generally encountered by majority of producers was cost of raw material especially wheat flour(66\%) which is imported and the few (26\%) who pointed out cost of fuel and on these areas many producers solicited for government intervention. Therefore, concerned authorities should wade into these informal sectors prevalent in many emerging economies so as to infuse modernity and regulation, this becomes necessary because this sector makes food available and accessible thereby reducing food insecurity for a large segment of society. Bread is the reported to be the chief source of calorie and protein in some regions of the developing world (Akobundu et al., 1988).

Table 3: Producers Response on GurasaProduction in NorthWestern Nigeria 
Experience in business (years)?

Source of skill?

Main raw material used?

Raw material mixing method?

Baking equipment type?

Type/source of fuel?

How do you determine doneness?

Is the businessprofitable?

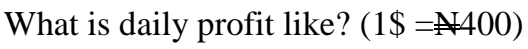

What are theProduction problems?

What area is assistance needed?
0-5(40.5), 6-11(44.3), 12-17(05.4), 18-23(2.7), <23(7.1)

Parents/relatives (91), Apprenticeship (09), Others (00)

Sugar (100), Flour(100), Yeast(100), others (00)

Manual (91.9), Mechanical (8.1), Others (00)

Local oven(81.0),Electric oven (18.9), Hot plate(00)

Charcoal(18.51), Cornstalk(75.68), firewood(13.92).

Appearance (56.76), Aroma (24.32), Taste (18.92).

Yes (100) No (00)

>1000(00) 1000-2099(26.2), 3000-4999(66.5),>7000(11.3)

Fuel (26), Cost of raw material (66), Storage (03), distribution means (05).

Working capital (56.76), Storage facility (36.22), logistics (7.02).

\section{Number of Respondents $=61$}

Nutritive value of gurasa from randomly selected producers $(n=10)$ is presented in Table 4. Significant variation $(\mathrm{p}<0.05)$ existed among the mean proximate values obtained. Moisture, crude protein, fat, ash, crude fiber, and carbohydrate varied significantly from $28.09-30.11 \%, 8.96-11.68 \%, 4.03-5.00 \%, 1.79$ $3.11 \%, 0.92-1.12 \%$ and $50.0-55.04 \%$. The food energy $(\mathrm{kcal} / 100 \mathrm{~g}$ ) varied from 288-297.95. Ash represents the mineral elements which are needed for healthy living as well as dietary fibre for regular bowel movement. Prolonged denial of nitrogen and energy substrates are responsible for protein-energy malnutrition. Adebayo-Oyetoro et al.(2016) reported a comparable values for $100 \%$ wheat pan bread: $28.94 \%$ moisture, $0.93 \%$ ash, $1.81 \%$ fat, $0.05 \%$ crude fibre, $10.25 \%$ protein, $52.98 \%$ carbohydrate, but gurasa samples obtained contained more fat, ash and fibre. Moisture, fat, protein, ash, fibre and carbohydrate pan wheat bread was reported by Amandikwa et al.(2015) to contain respectively: $26.82 \%, 5.10 \%, 9.25 \%$, $2.00 \%, 0.12 \%$ and $56.71 \%$. These results are comparable because unlike flatbreads elsewhere which are usually made with flour of high extraction, Nigerian gurasa and pan bread are produced from the same refined flour available in the open markets. Ereifej and Rababah (2006) produced balady bread from wheatbarley blends, the control(Unified flour) contained: protein $10.5 \%$, fat $1.2 \%$, fibre $0.4 \%$, ash $1.6 \%$ and carbohydrate $86.3 \%$ on dry basis, this indicates Nigerian gurasa had greater nutrient density despite that the proximate values were reported on as-is basis. Meininger(2017) reported that 2000 calorie-diet per day requires protein, fat, dietary fibre and carbohydrate intake per day of 50g (200-700 calories), 65g (400900calries) $25 \mathrm{~g}$ and 300g (900-1300calories) respectively. FAO/WHO/UNU(2001) recommends a minimum of $0.6 \mathrm{~g}$ protein $/ \mathrm{kg} / \mathrm{day}$. The nutrient density of gurasa although it compares favourably with available modern bread in the market yet its fibre contents, protein quality and quantity requires supplementation. Indrani et al.(2011) increased the protein, fat, dietary fibre and mineral contents of Indian parotta bread using a multigrain blends. In this way the recommended daily nutrient intake could be met. According to IITA (2004), the national (Nigeria) food consumption and nutrient survey of 2001-2003 reveals that $42 \%$ of children were stunted,25\% underweight and $9 \%$ wasted. Nigeria has one the of the highest incidence of malnutrition in Africa due to prolonged deprivation of both calorie and nitrogen substrates (eHealthAfrica,2016).

Table 4: Proximate Composition(\%) of Gurasa from Ten Different Producers in Northwestern Nigeria

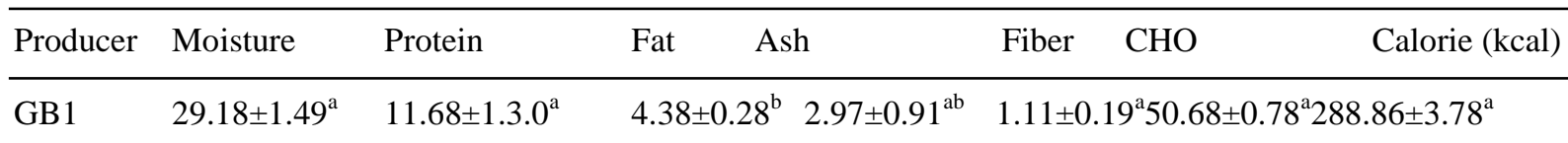




\begin{tabular}{|c|c|c|c|c|c|c|c|}
\hline $\mathrm{B} 2$ & $28.09 \pm 0.67^{\mathrm{a}}$ & $9.84 \pm 0.00^{\mathrm{c}}$ & $4.27 \pm 0.42^{\mathrm{b}}$ & $1.79 \pm 0.35^{\mathrm{c}}$ & $0.97 \pm 0.01^{\mathrm{ab}}$ & $55.04 \pm 0.98^{\mathrm{a}}$ & $297.95 \pm 4.06^{\mathrm{a}}$ \\
\hline GB3 & $28.88 \pm 0.33^{\mathrm{ab}}$ & $10.19 \pm 0.61^{\mathrm{bc}}$ & $4.12 \pm 0.40^{\mathrm{bc}}$ & $1.89 \pm 0.29^{c}$ & $0.92 \pm 0.29^{\mathrm{ab}}$ & $54.00 \pm 1.45^{\mathrm{ab}}$ & $293.84 \pm 2.53^{\mathrm{a}}$ \\
\hline SB4 & $29.10 \pm 0.33^{\mathrm{a}}$ & $11.63 \pm 0.11^{\mathrm{c}}$ & $5.00 \pm 0.13^{\mathrm{b}}$ & $2.76 \pm 0.02^{\mathrm{b}}$ & $0.96 \pm 0.29^{\mathrm{ab}}$ & $50.55 \pm 0.44^{\mathrm{b}}$ & $293.72 \pm 2.10^{\mathrm{a}}$ \\
\hline iB5 & $28.37 \pm 1.79^{\mathrm{b}}$ & $10.55 \pm 0.61^{\mathrm{b}}$ & $4.03 \pm 088^{c}$ & $3.11 \pm 0.62^{\mathrm{a}}$ & $1.12 \pm 0.11^{\mathrm{a}}$ & $52.82 \pm 0.20^{\mathrm{a}}$ & $289.75 \pm 2.48^{\mathrm{a}}$ \\
\hline sB6 & $29.12 \pm 0.10^{\mathrm{a}}$ & $10.87 \pm 0.28^{\mathrm{b}}$ & $4.16 \pm 0.41^{\mathrm{bc}}$ & $2.57 \pm 0.48^{\mathrm{c}}$ & $1.08 \pm 0.32^{\mathrm{a}}$ & $52.20 \pm 0.32^{\mathrm{a}}$ & $289.72 \pm 2$. \\
\hline SB7 & $28.62 \pm 0.58^{\mathrm{ab}}$ & $11.20 \pm 0.11^{\mathrm{ab}}$ & $4.21 \pm 0.22^{\mathrm{b}}$ & $1.96 \pm 0.22^{\mathrm{c}}$ & $1.11 \pm 0.08^{\mathrm{ab}}$ & $52.90 \pm 0.23^{\mathrm{b}}$ & $294.29 \pm 1$ \\
\hline $\mathrm{B} 8$ & $30.11 \pm 0.58^{\mathrm{ab}}$ & $11.20 \pm 0.11$ & $4.21 \pm 0.22^{\mathrm{b}}$ & $1.96 \pm 0.22^{\mathrm{c}}$ & $1.11 \pm 0.08^{\mathrm{ab}}$ & $52.90 \pm 0.23^{\mathrm{b}}$ & $294.29 \pm 1$ \\
\hline B9 & $28.10 \pm 0.58^{\mathrm{ab}}$ & $11.20 \pm 0.11$ & $.31 \pm 0.22^{\mathrm{b}}$ & $1.26 \pm 0.22^{\mathrm{c}}$ & $1.17 \pm 0.09^{\mathrm{ab}}$ & $52.90 \pm 0.24^{\mathrm{b}}$ & $299.30 \pm 1$ \\
\hline B10 & $30.11 \pm 0.58^{\mathrm{ab}}$ & $11.20 \pm 0.11^{\mathrm{ab}}$ & $4.21 \pm 0.22^{\mathrm{b}}$ & $1.96 \pm 0.22^{\mathrm{c}}$ & $1.11 \pm 0.08^{\mathrm{ab}}$ & $52.90 \pm 0.23^{\mathrm{b}}$ & $294.29 \pm 1.9$ \\
\hline
\end{tabular}

GB = Gurasa bread, CHO=carbohydrate

The physical properties of gurasa samples are presented in Table 5. The diameter, weight, volume and specific leaf volume varied significantly $(\mathrm{p}<0.05)$ from $14.82-18.28 \mathrm{~cm}, 108.34-119.27 \mathrm{~g}, 211.96 \mathrm{ml}-260.17 \mathrm{ml}$ and $1.93-2.22 \mathrm{ml} / \mathrm{g}$. Flat breads are noted for low specific volume, round shape ,therefore the diameter depends on the type of flat bread and the unit size desired by the consumers and the region it is located. Ereifej and Rababah (2006) recorded a decrease in physical parameters of balady bread on replacement of wheat with barley flour, the weight, volume and diameter of the control produed with Unified flour are 93.8g, $181.0 \mathrm{ml}$ and $15.3 \mathrm{~cm}$ respectively, indicating a loaf specific volume of $1.81 \mathrm{ml} / \mathrm{g}$. The values are comparable to the results shown in Table 5. On the contrary, Mousa et al.(1979) reported a specific loaf volume for balady of $9.5-12 \mathrm{ml} / \mathrm{g}$, this flat bread is usually made with wheat flour of higher extraction and inclusion of additives.

Table5. Physical Characteristic of Gurasa Samples Obtained from 10 Producers inNorthwesternNigeria

\begin{tabular}{|c|c|c|c|c|}
\hline Sample code & Diameter (Cm) & weight (g) & Volume (ml) & SpecificVolume \\
\hline GB 1 & $18.28 \pm 0.34^{\mathrm{a}}$ & $120.35 \pm 2.52^{\mathrm{a}}$ & $260.17 \pm 0.86^{\mathrm{b}}$ & $2.16 \pm 0.05^{\mathrm{ab}}$ \\
\hline GB2 & $15.35 \pm 0.23^{\mathrm{c}}$ & $108.34 \pm 3.06^{\mathrm{c}}$ & $214.95 \pm 1.08^{\mathrm{d}}$ & $1.98 \pm 0.07^{\mathrm{b}}$ \\
\hline GB3 & $18.18 \pm 0.34^{\mathrm{a}}$ & $122.00 \pm 2.52^{\mathrm{a}}$ & $252.94 \pm 3.51^{\mathrm{ab}}$ & $2.10 \pm 0.04^{\mathrm{ab}}$ \\
\hline GB4 & $14.82 \pm 0.16^{\mathrm{d}}$ & $111.32 \pm 1.91^{\mathrm{b}}$ & $211.96 \pm 2.55^{\mathrm{d}}$ & $1.93 \pm 0.04^{\mathrm{b}}$ \\
\hline GB5 & $17.57 \pm 0.59^{b}$ & $118.33 \pm 1.53^{\mathrm{a}}$ & $243.59 \pm 0.52^{\mathrm{b}}$ & $2.06 \pm 0.02^{\mathrm{ab}}$ \\
\hline GB6 & $16.82 \pm 0.35^{\mathrm{bc}}$ & $117.68 \pm 2.13^{\mathrm{ab}}$ & $239.89 \pm 3.87^{\mathrm{b}}$ & $2.01 \pm 0.03^{\mathrm{b}}$ \\
\hline GB7 & $15.11 \pm 0.30^{\mathrm{c}}$ & $109.80 \pm 3.00^{\mathrm{c}}$ & $213.64 \pm 1.18^{\mathrm{d}}$ & $1.94 \pm 0.07^{\mathrm{b}}$ \\
\hline GB8 & $16.09 \pm 0.23^{\mathrm{bc}}$ & $112.82 \pm 2.00^{\mathrm{c}}$ & $228.27 \pm 8.32^{\mathrm{c}}$ & $2.02 \pm 0.07^{\mathrm{b}}$ \\
\hline GB9 & $18.11 \pm 0.33^{\mathrm{a}}$ & $119.27 \pm 11.20^{\mathrm{a}}$ & $236.27 \pm 0.80^{\mathrm{b}}$ & $2.01 \pm 0.08^{\mathrm{b}}$ \\
\hline GB10 & $17.31 \pm 0.31^{b}$ & $115.61 \pm 2.11^{\mathrm{b}}$ & $250.07 \pm 0.75^{\mathrm{b}}$ & $2.22 \pm 0.02^{\mathrm{a}}$ \\
\hline
\end{tabular}

\section{GB $=$ Gurasa bread}

\section{Conclusion}

Male adolescents were dominantly involved in gurasa production and they are of school age and consumption is wide spread especially the under 30. States bordering Kano harbor the greatest number of producers and consumers. Better eating quality and cheapness are the driving force behind preference for gurasa over pan bread. Although, keeping quality is claimed to be high but higher fat and moisture contents coupled with lack of refrigeration for leftovers negates such claim. The profitability in gurasa business can be further enhanced through provision of soft loan to the producers or reduction of the cost of flour and sugar the main raw materials. Nutritive quality of gurasa is not remarkably different from that of available pan bread in the market since both are made from the same refined flour. It is suggested that regular sensitization of producers on good manufacturing and hygienic practices are needed to ensure public safety;moreover partial supplementation of the refined wheat flour with any of the readily available pulse flour will improve the nutritional quality of gurasa, a flat bread relished by north-western Nigerians. 
[1] Adebayo-oyetoro, A.O, Ogundipe, O.O and Adelepo, K..N.(2016) Quality assessment and consumer acceptability of bread from wheat and fermented banana flour. Food Science and Nutrition journal 33(1):12-17

[2] AACC(2000) Approved Methods of the America Association of Cereal Chemists,Vol.2, 17th Edition, Official Methods 923.03, 923.05, 4.5.01, 925.09, 962.09, and 979.09. American Association of Cereal Chemists. St. Paul MN, USA.

[3] Akobundu, E.N.T.,Ubaonu, C.N.,Ndupuh C.E.(1988) Studies on baking potential of non-wheat composite flours. Journal Food Science Technology, 41:211-214.

[4] Coskuner, Y., Karababa, E.and Ercan R 1999 "Feat bread production technology. Journal of Food volume 24,83-97

[5] D.Indrani, P.Swetha, C. Somuya, F.Rajiv and G.V. Rao (2011)"Effects of multigrain on rheological, microstructural and quality characteristics of north Indian parotta, an Indian flat bread" LWF Food Science and technology, Vol. 44(3):719-224

[6] D.Indrani, S..J. Rao, K.U Sankan and G.V Rao( 2000). "Changes in the physical-chemical and organoleptic characteristics of parotta during storage. Food Res. International, volume 33(5):323-329

[7] eHealthAfrica(2016) Sweet potatoes:Realistic answer for Nigerian's nutrition crises. Available: ehealthafrica.org/latest/2016/4...,accessed on 17th June,2017.

[8] Ereijej K.I, Al-Mahasneh and Rababah, T.M.( 2016). Effects of barley flour on quality of balady bread. International journal Food properties 9, 39-49

[9] Faridi H. A. and G.L Rubenthaler (1983). "Ancient bread and a new science. Understanding flat breads taste, flavor, texture and appearance.] Cereals Food World. 28(10:527-540

[10] FAO(2009) "Declaration of the world food summit on food and security". Food and Agricultural Organization of the United Nations, Rome. Available: www. Fao.org.2009/WSF09 Declaration FAO

[11] FAO(2016) Nigeria Food Security and Vulnerability Survey. Food and Agricultural Organization of the United Nations, Rome. Available: www. Reliefweb.int/report/Nigeria/. Accessed on 20th March,2018.

[12] Giami, S.Y, Y. Amasi and G Ekiyor,( 2004). Comparison of bread making properties of composite flour from kernels of roasted and boiled African bread fruit seeds. Journal of Raw material Research,1:16-25.

[13] Gocmen, D., Inkaya, A.N. and E. Aydin (2009) Flat breads. Bulgarian Journal of Agricultural Science, 15(4):298-306

[14] IITA (2004) National Food Consumption Nutrition survey, 2001-2003: Summary. B-maziya-Dixon, I.O. Akinyele, E.B. Oguntona, S.Nokoe, R.A. Sanusi and E. Harris (eds). Available: catalogue.ihsn.org/index.php/catalog, accessed on $21 \mathrm{st}$ March,2018.

[15] Ibrahim A.Yusha'u (2015) Gura: Food for royals and the poor. Available:dailytrust.com.ng/------/122012. Html accessed on 20/03/2017./20th March 2017

[16] Ijah, O.J.J., Auta, H.S, Aduloja, M.O and Ariansiola, S.A(.2014) Microbiological, nutritional and sensory qualities of bread produced from wheat and potato flour blends. International journal of Food Science and Technology volume 2014(2014), http:/dx.doi.org/10.1153/2014/671701

[17] Khoury, C.K, Bjorkman, A.D, Dempewolf, H, Ramirez-Villegas, L, Jarvis, A, Riesberg, L.H, Struk, P.C. (2014) "Increasing homogeneity in global food supplies and the implication for food security" PNAS. III (II): 4001 -4006

[18] Mousa, E.I .,Ibrahim R.H.,Shuey, W.C.,and Manval R.D.(1979) Influence of wheat classes, baking methods on Egyptian Balady bread. Cereal chemistry. 56: 563-566

[19] Meininger K (2017) FDA Daily Nutritional requirements. Available: www. Livestrong.com/article/ 44O4, accessed on April 28th ,2018.

[20] NPU(2018) National population Commission: Current estimated Nigerian population. Available:population.gov.ng/...

[21] Pahwa, A, Kaur Amarjeet and puri Ritika: (2016) Influence of hydrocolloids on the quality of major flat breads ; A Review.Journal of Food Processing, vol.(2016) http://dx.doi .org/10.1155/2016/87050258

[22] Qarooni, J (1996) Quality of flat breads In:Flat bread Technology pp. 141-158, Springer, Boston MA.

[23] Quail, K.J.(1990) Effects of baking temperature/time conditions and dough thickness on Arabic bread quality. Journal of the Science of Food and Agric., vol. 53:527-540

[24] Shewry, P.R.,Halford, N.G. and Tatham, A.S. (1992) High molecular weight subunits of wheat glutenin. Journal of Cereal Science, 15:105-120.

[25] Wani A.I, Sogl, D.S. Sharma, P and Singh B (2016). Physiochemical and pasting properties of unleavened white flour bread(chapatti) as affected by addition of pulse flour. Cogent Food and Agric. 2(1): 5-20. 